\title{
CHARACTERISTIC OF THE MATHEMATICALLY GIFTED STUDENT
}

[CHARAKTERISTIKA MATEMATICKY NADANEHO ZIAKA]

\section{Dusan Fabik}

\section{DOI: 10.18355/PG.2015.4.2.210-219}

\begin{abstract}
The present work aims at closer understanding the mathematically gifted student. It defines the term mathematical talent including its most up-todate concepts. It provides information on specifics of mathematically gifted students which result in specific pedagogical resources and tools for supporting these students. They are mainly focused on proper development of mathematical talent. The methodological part of the work studies the personality of mathematically gifted student and compares it with that of a non-gifted student. The research group consisted of eighty students (38 gifted and 42 ordinary) with the average age of 16.6 years. The main method used here was the NEO Five-Factor Inventory. The results of the work have proven difference in the personality structures of mathematically gifted students and standard ones.
\end{abstract}

\section{Key words}

mathematical talent, educational support, personality structure of mathematically gifted student

\begin{abstract}
Abstrakt
Práca sa zameriava na bližšie poznanie matematicky nadaného žiaka. Definuje matematické nadanie a predstavuje jeho najaktuálnejšie koncepty. Ďalej sprostredkováva informácie o špecifikách matematicky nadaných žiakov, ktoré vyúst'ujú do konkrétnych prostriedkov a podnetov pre pedagógov na podporu týchto žiakov. Venuje sa najmä spôsobom správneho rozvíjania matematického nadania. Metodologická čast' skúma osobnost' matematicky nadaného žiaka a porovnáva ju s bežných žiakom. Výskumnú vzorku tvorí 80 žiakov (38 matematicky nadaných, 42 bežných) s priemerným vekom 16,6. Hlavná použitá metóda je pät'faktorový osobnostný inventár NEO-FFI. Výsledky práce preukázali rozdielnu osobnostnú štruktúru matematicky nadaných žiakov od bežných.
\end{abstract}

\section{Kl’účové slová}

matematické nadanie, podpora vo vzdelávaní, osobnostná štruktúra matematicky nadaných žiakov

\section{Matematické nadanie}

Matematické nadanie nie je jednoznačne definované, podobne ako všeobecné intelektové nadanie má viacero prístupov a náhl'adov. Napr. A. Vasutova (2012) vymedzuje matematické nadanie ako komplex vysoko 
nadpriemerných všeobecných rozumových schopností, mimoriadne rozvinutých matematických schopností, tvorivého myslenia a záujmu o matematiku, ktorý sa prejavuje vysokou motiváciou a nasadením pri riešení úloh. V. Burjan (2005) zase definuje matematické nadanie v troch základných rovinách: všeobecné intelektové predpoklady, motivácia a aktuálna vedomostná výbava. Polya (Mann, 2006) vysvetl'uje matematický talent dvomi hlavnými faktormi: informáciami (vedomosti) a know-how (schopnosti ako kreativita, rozhodnost', originalita a samostatnost' v riešení úloh). Mierne odlišný náhl'ad má B. Sriramana (2009). Do konceptu matematického nadania patrí podl'a neho matematická inteligencia, ktorá je považovaná za dôležitý indikátor všeobecnej inteligencie. B. Sriraman (2009) definuje matematickú inteligenciu 10-timi faktormi:

abstrakcia, generalizácia a rozlíšenie matematických štruktúr,

- používanie techník spracovania informácií,

- schopnost' úspešne zvládnut' princípy logického uvažovania a inferencie,

- analogické, heuristické myslenie,

- flexibilita a reverzibilita matematických operácií,

- intuitívne povedomie o matematických dôkazoch,

- samostatné objavovanie matematických princípov,

- $\quad$ schopnost' aplikovat' procesy rozhodovania sa pri riešení situácií,

- schopnost' vizualizácie problému a jeho súvislostí,

- $\quad$ rozlišovanie medzi empirickými a teoretickými princípmi.

Z nášho pohl'adu sa javí ako najvhodnejšie východisko D. Malinovej (2013:

2), ktorá chápe matematické nadanie ako ,špecifickú skupinu intelektovo nadaných, ktorí majú nadpriemerne rozvinuté matematické schopnosti“. Preto sú pre jedincov s matematickým nadaním typické „Všeobecné““ charakteristiky nadaných, k čomu sa pridávajú charakteristiky špecifické, vzt'ahujúce sa $\mathrm{k}$ matematike.

Z pohl'adu rozvoja osobnosti nadaných, môžeme ich "všeobecné" schopnosti, vedomosti a spôsobilosti rozčlenit' do troch hlavných okruhov (por. Hribkova, Laznibatova, Juraskova; in Kovarova, Klugova, 2010; Laznibatova - Vrankova, 2005; Clark, 2012): kognitívne a nekognitívne charakteristiky a charakteristiky učenia. Medzi kognitívne charakteristiky a prejavy radíme intelektové charakteristiky - samostatné získavanie informácii, schopnost' správneho a rýchleho zovšeobecnenia, rozvinuté kritické myslenie, záujem o náročné témy; d’alej tvorivé charakteristiky množstvo originálnych nápadov, expresívnost' v nápadoch a vyjadrovaní, flexibilita v myslení, nekonvenčné uvažovanie, ochota riskovat' a pamät' vynikajúca pamät', dobré pozorovacie schopnosti. Z pravidla vo všetkých kognitívnych charakteristikách nadaní žiaci prevyšujú svojich rovesníkov. V rámci nekognitívnych charakteristikách hovoríme o týchto oblastiach: motivačná - prevaha vnútornej motivácie nad vonkajšou, zameranie k ciel'u; emocionálna - menej vyzretí ako ich rovesníci, vyžadujú intenzívnejšiu emocionálnu podporu a prijatie, zvýšene citlivý na kritiku, silné estetické cítenie; sociálna - vyhl'adávajú starších žiakov, nesúlad medzi potrebou zvýšenej vol'nosti a dožadovania sa zvýšenej pozornosti 
vzhl'adom k svojej osobe. Charakteristiky učenia - dobrá adaptácia v novom učebnom prostredí, preferencia individuálneho pred skupinovým, nezáujem o mechanické a pamät’ové učenie, štruktúrované riešenie problémov.

K špecifickým charakteristikám žiakov s matematickým nadaním patria podl'a Makridesa (Malinova, 2013) tieto atribúty:

- vel'ký záujem o matematiku;

- bystré reakcie, rýchle porozumenie a aplikácia matematických myšlienok;

- schopnost' abstraktne mysliet' a pracovat' a uvedomovat' si matematické vzt'ahy a súvislosti;

- schopnost' pracovat's matematickými úlohami flexibilne a tvorivo, nie stereotypne;

- schopnost' prenášat' poznatky do nových, neprebádaných matematických situácii.

Podl'a Montgomery County Public Schools (2015) musí matematicky nadaný jedinec nezávisle preukázat' mnohé matematické schopnosti a vlastnosti:

- matematické myslenie a povedomie o kvantitatívnych informáciách vo svete okolo neho;

- mysliet' logicky a symbolicky o kvantitatívnych, priestorových a abstraktných vzt'ahoch;

- vnímat', vizualizovat' a zovšeobecňovat' číselné a nečíselné vzory a vztahy;

- zdôvodňovat' analyticky, deduktívne a induktívne;

- pracovat', komunikovat' a zdôvodnit' matematické koncepty kreatívnym a intuitívnym spôsobom, a to tak ústne ako aj písomne;

- preniest' naučené do nových situácií;

- formulovat' matematické otázky za účelom rozšírenia alebo uplatnenia určitých konceptov;

- hl’adat' riešenie zložitých, „chaotických“ alebo „zle definovaných“ úloh;

- usporadúvat' informácie a údaje mnohými rôznymi spôsobmi a ignorovat' irelevantné údaje;

- rýchlo pochopit' matematické koncepty a stratégie so schopnost'ou si ich zapamätat';

- dat' do súvisu matematické koncepty v rámci jednotlivých obsahových oblastí a skutočných životných situácii;

- riešit' problémy s niekol'kými riešeniami;

- používat' matematiku so sebavedomím, riskovat' pomocou matematických koncepcií a stratégií;

- uplatňovat' rozsiahlejšie a hlboké znalosti o rôznych hlavných matematických témach;

- použit' odhad a mentálne výpočtové stratégie. 


\section{Špecifiká matematicky nadaných žiakov}

Matematicky nadaní študenti sú schopní nájst' riešenie úlohy s neobvyklou rýchlost'ou a presnost'ou. Sú schopní vidiet' vzt'ahy medzi témami, konceptmi a myšlienkami bez zásahu formálneho usmernenia špecificky zameraného na konkrétny obsah (Davis - Rimm - Siegle, 2010). Vzhl'adom na svoje intuitívne chápanie matematickej funkcie a procesov, bežne $\mathrm{v}$ priebehu riešenia úlohy preskakujú niektoré kroky. Títo žiaci preukazujú nerovnomerný profil matematického poznania a vývoja, pretože niektorí sú ovel'a lepší v tvorbe konceptu ako pri samotnom výpočte (Rotigel, in Rotigel - Fello, 2004). Často chcú vediet' viac o tom ,ako“ a „prečo“ v súvislosti s matematickými úlohami, než spoznat' proces výpočtu, teda „ako na to“. Preferujú učenie do híbky a chcú sa radšej naučit” všetko, čo sa dá o určitej matematickej myšlienke, než aby po chvíli prešli $\mathrm{k}$ výučbe nového matematického konceptu. Viest' výučbu matematiky aj na základe záujmu študentov je zrejme vhodný spôsob ako zabránit' sklamaniu, ktoré nastane, ak pedagóg rigidne vyžaduje, aby sa prešlo $\mathrm{k}$ d’alšej téme. Dá sa predpokladat', že lineárnejší prístup vo výučbe matematiky nadaným det’om vyhovuje viac ako špirálovité osnovy, ktoré sa vyskytujú $\mathrm{v}$ učebniciach a obyčajne s nimi pracujú pedagógovia. Napríklad, ked' sa vyučuje téma desatinných miest, det'om s matematickým talentom sa môže hned' umožnit', aby sa ponorili do témy ovel'a hlbšie, naučili sa praktické aplikácie pre desatinné miesta a prepojenia medzi desatinnými miestami či d’alšími matematickými témami. D. Pletan et al. (1995) taktiež upozorňujú, že učitelia, ktorí postupujú len podl'a osnov a nepružne prechádzajú cez mnohé učivá matematiky, len t’ažko rozpoznajú a vychovajú mladých matematikov. Študenti obdarení matematickým myslením a riešením problémov potrebujú taktiež väčšiu híbku a šírku tém a otvorené príležitosti na riešenie zložitejších problémov (Monks - Ypenburg, 2002; Rotigel Fello, 2004).

Niektorí autori (napr. Diezmann - Watters, 2002) členia matematicky nadaných žiakov podl'a ich pokročilej schopnosti uvažovat' bud' analyticky, alebo priestorovo. Analyticky nadaní študenti sú väššinou rýchlymi a presnými pracovníkmi, ktorí sú schopní formulovat' svoju myšlienkovú postupnost'. Naopak, priestorovo nadaní študenti môžu dosahovat' horšie výsledky $\mathrm{v}$ škole $\mathrm{z}$ dôvodu typického dôrazu na analytické úlohy a môžu mat' výrazné problémy formulovat' svoje riešenie. Priestorovo nadaní študenti sú najlepší pri vizuálno-priestorových matematických úlohách a používaní priestorových nástrojov a techník, ako sú diagramy či vizualizácie. Priestorovo nadaní študenti tiež majú tendenciu zaujímat' sa o priestorovo orientované aktivity, napr. kreslenie, čítanie máp, stavebníctvo alebo šach. Preto je aj identifikácia týchto študentov závislá na poskytovaní relevantných príležitostí kde môžu preukázat' svoje schopnosti. Ale aj napriek tendencii priestorovo nadaných študentov mat' $\mathrm{v}$ škole horšie výsledky sa udáva, že sú to práve títo žiaci, ktorých schopnosti spôsobujú častejšie tvorivé objavy $\mathrm{v}$ matematike a prírodných vedách než nadpriemerné analytické schopnosti. Je pravdepodobné, že priestorovo nadaní majú výhodu v tom, že sú schopní spracovat' informácie súčasne, 
nie sekvenčne. Preto sú schopní abstrahovat' rozsiahle prepojenia medzi konceptmi a postupmi a t’ažit' z kognitívnych nástrojov, napr. analógie.

Ak sa zameriame na osobnost' matematicky nadaného žiaka zistíme, že sa jedná o prakticky neprebádanú oblast'. Môžeme síce nájst' množstvo výskumov zameraných na osobnost' všeobecne intelektovo nadaného žiaka, no so žiakmi so špecifickým matematickým talentom nájdeme len málo prác. K nedostatku výskumov na túto tému zrejme prispeli dnes už staršie práce (napr. Dockal et al., 1987), ktoré sú názoru, že k nadpriemerným výkonom v matematike nie sú potrebné žiadne výnimočné alebo špeciálne osobnostné vlastnosti. Konštatujú dokonca, že "matematicky nadaný jednotlivec sa štruktúrou osobnosti nijako nevymyká z hraníc normy platnej pre celú populáciu" (Dockal et al., 1987: 89). Štúdií, ktoré by vierohodne podložili túto tézu je však nedostatok. Aktuálne práca V. Kompanovej (2013) uvádza niektoré špecifické črty, špeciálne pre matematicky nadané deti (hoci nie všetky sú osobnostné):

- sebaistota

- zodpovednost' za povinnost'

- sebakritika

- uzavretost'

- matematické myslenie je ako u vekovo starších žiakov

- l'ahko si zapamätajú matematický materiál

- podmienky úloh chápu analyticko-synteticky

- pružné myslenie

- hl'adanie racionálne riešenia

- priestorové videnie

- $\quad$ schopnost' manipulácie s abstraktnými pojmami

Ako vidíme, aktuálna odborná literatúra hovorí o viacerých rozdieloch $\mathrm{v}$ osobnostnej štruktúre medzi nadanými žiakmi matematiky a bežnými žiakmi. V d'alších častiach práce budeme aj my skúmat' tieto rozdiely.

\section{Ako podporovat’ matematicky nadaných žiakov}

Študenti nadaní na matematiku majú potreby, ktoré ich podstatne odlišujú od ostatných študentov. D. Johnson (2000) hovorí o troch kl'účových oblastiach: tempo, ktorým sa učia; hĺbku porozumenia a záujmy, ktoré majú. Tieto oblasti kladú na učitel'ov zvýšené nároky:

Po prvé učitelia sa potrebujú dostatočne vzdelávat' o nadaných študentoch. To zahŕňa schopnost' rozpoznat' matematicky nadaných žiakov, uvedomit' si ich problémy, poznat' účinné stratégie pri ich výučbe a byt' informovaní o legislatívnych ustanoveniach vzdelávania nadaných žiakov.

Po druhé, učitelia by mali pre týchto žiakov poskytovat' dostatočne náročné úlohy a podporovat' proces vzdelávania z týchto úloh (Colangelo - Davis, 2003). Podpora by mala zahŕňat' modifikáciu obtiažnosti úloh, možnost' vyniknút' viacerým študentom podl'a typu úloh, poskytnutie optimálneho riešenia danej úlohy a využívanie rôznych technických či obrazových pomôcok pre urýchlenie myslenia. M. Diezmann a J. Watters (2001) dodávajú, že je vhodné zaradit' skupinovú aj individuálne prácu. Je však nutné dbat' na fakt, že nadaní študenti dávajú pri relatívne l'ahkých úlohách 
prednost' samostatnej práci a až pri dostatočne náročnej úlohe preferujú skupinovú prácu.

Po tretie, učitel' by mal $\mathrm{v}$ prvom rade podporovat' rozvoj schopnosti samostatne uvažovat', pretože práve to je hlavný pilier tvorivosti $\mathrm{v}$ matematike (Johnsen - Kendrick, 2005). To zahŕňa diskusiu o danej úlohe, dôkazy, argumentáciu či spoločné zdiel'anie myšlienok.

Po štvrté, učitelia by si pri plánovaní výučby mali odpovedat' na niekol'ko otázok:

1. Poskytujú úlohy možnost' vidiet' žiakove schopnosti, motiváciu a skúsenosti?

2. Sú osnovy kvalitatívne odlišné, aby splnnali potreby tej, ktorej matematickej skupiny žiakov?

3. Je poskytnuté hodnotenie, ktoré umožňuje zachytit' rozdiely v híbke porozumenia daného učiva?

Kladné zodpovedanie týchto otázok zabezpečuje kvalitnú a podnetnú výučbu.

\section{Výskumný problém}

Ciel' nášho výskumu je zistit' osobnostné charakteristiky matematicky nadaných adolescentov. Vzhl'adom na rozdielne všeobecné i špecifické charakteristiky matematicky nadaných žiakov od bežných predpokladáme významné rozdiely v osobnostnej štruktúre.

\section{Výskumná otázka}

Vzhl'adom na poznatky z prehl'adu relevantnej odbornej literatúry a v súlade s ciel'mi práce sme si stanovili túto výskumnú otázku:

Existujú rozdiely $\mathrm{v}$ osobnostnej štruktúry matematicky nadaných adolescentov a bežných adolescentov?

\section{Výskumná vzorka}

Nášho výskumu sa zúčastnilo 80 respondentov - chlapcov. Matematicky nadaných jedincov bolo 38 (študenti Školy pre mimoriadne nadané deti a Gymnázium v Bratislave); bežných adolescentov bolo 42 (študenti Strednej odbornej školy chemickej v Bratislave). Pomocou deskriptívnej štatistiky sme zistili, že vekové rozloženie výskumnej je (AM=16,6; $\mathrm{Md}=16,5$; $\mathrm{Mo}=16)$. Minimálny vek respondenta bol 15 rokov, maximálny 19 rokov. Priemerný vek matematicky nadaných adolescentov bol $(\mathrm{AM}=16,263)$, priemerný vek bežných adolescentov je $(\mathrm{AM}=16,905)$.

\section{Metódy a techniky výskumu}

Podobne ako udáva D. Malinova (2013) aj v tejto práci je matematické nadanie definované a ponímané kombináciou dvoch základných faktorov: intelektové nadanie a vysoko rozvinuté matematické schopnosti.

1. Intelektové nadanie je vymedzené ako „výnimočná všeobecná intelektová spôsobilost', pričom u nadaných možno dokázat' výnimočnú vývinovú úroveň a táto úroveň je po dlhšie obdobie do vysokej miery konštatná" (Laznibatova, 2007: 57). Ako kritérium 
nadania ponímame celkovú úroveň intelektových schopností nachádzajúcich sa v pásme horných $2 \%$ populačného ročníka (IQ 130), za predpokladu úrovne tvorivosti aspoň $\mathrm{v}$ pásme priemeru $\mathrm{v} v$ súlade $\mathrm{s}$ Metodickými pokynmi na zarad'ovanie detí do špeciálnych výchovnovzdelávacích programov pre intelektovo nadaných žiakov (2008) schválených Ministerstvom školstva SR.

2. Rozvinuté matematické schopnosti sú definované úrovňou schopnosti riešit' matematické úlohy. Za hranicu vysoko rozvinutých matematických schopností považujeme percentil 90. Pri určovaní tejto hranice je vhodné použit' objektívne meracie nástroje, o ktorých sa píše nižšie.

Všeobecné intelektové nadanie jedincov boli určené pomocou inteligenčného testu WISC III (Wechsler, 2006). Kritériom pre diagnostikovanie nadania bola hranica IQ 130.

Pre určenie rozvinutých matematických schopností sme použili inteligenčný test IST 70 (Amthauer, 1993) v úprave J. Vonkomera. Kritériom definovania vysoko rozvinutých matematické schopnosti bol 90-i percentil v subteste "počtové úlohy".

Na posúdenie osobnostnej štruktúry sme použili pät'faktorový osobnostný inventár NEO-FFI (autori P. T. Costa a R. R. McCrae), preklad slovenského vydania I. Ruisel, P. Halama (2001), ktorý meria pät' všeobecných dimenzií osobnosti: neurotizmus, extraverziu, otvorenost', prívetivost' a svedomitost'.

Výskum má korelačný charakter, ktorý je založený na skúmaní vzt’ahov medzi premennými, pričom neovplyvňujeme premenné, iba ich meriame a hl'adáme vzt’ahy. Na spracovanie získaných dát sme využili štatistický program SPSS 20.0. Na výpočet normálneho rozloženia dát vo vzorke sme použili Kolmogorov-Smirnovov test normality. Normálne rozloženie sme nezistili v žiadnej sledovanej položke, preto na vyhodnocovanie používame neparametrické testy.

\section{Analýza výsledkov výskumu a diskusia}

Existujú rozdiely $\mathrm{v}$ osobnostnej štruktúre matematicky nadaných adolescentov a bežných adolescentov?

Tabul'ka 1 Výsledky Mann-Whitneyho testu v osobnostných škálach u matematicky nadaných a bežných adolescentov

\begin{tabular}{|l|l|c|c|c|c|c|}
\hline \multicolumn{1}{|c|}{ Škála } & Skupina & N & Md & MR & u-test & sig. \\
\hline Neurotizmus & $\begin{array}{l}\text { Mat. } \\
\text { nadaní }\end{array}$ & 38 & 18 & 31,55 & 458,00 & $\mathbf{0 , 0 0 1}$ \\
\cline { 2 - 5 } & Bežní & 42 & 23 & 48,6 & & \\
\hline \multirow{2}{*}{ Extraverzia } & $\begin{array}{l}\text { Mat. } \\
\text { nadaní }\end{array}$ & 38 & 34 & 44,66 & 640,00 & 0,127 \\
\cline { 2 - 5 } & Bežní & 42 & 31 & 36,74 & & \\
\hline Otvorenost' & $\begin{array}{l}\text { Mat. } \\
\text { nadaní }\end{array}$ & 38 & 26 & 39,76 & 770,00 & 0,787 \\
\hline
\end{tabular}




\begin{tabular}{|l|l|c|c|c|c|c|}
\hline & Bežní & 42 & 27 & 41,17 & & \\
\hline Prívetivost' & $\begin{array}{l}\text { Mat. } \\
\text { nadaní }\end{array}$ & 38 & 27 & 42,16 & 735,00 & 0,543 \\
\cline { 2 - 5 } & Bežní & 42 & 25 & 39 & & \\
\hline \multirow{2}{*}{ Svedomitost' } & $\begin{array}{l}\text { Mat. } \\
\text { nadaní }\end{array}$ & 38 & 29 & 41,55 & 758,00 & 0,700 \\
\cline { 2 - 5 } & Bežní & 42 & 28 & 39,55 & & \\
\hline
\end{tabular}

Na základe uvedenej tabul'ky môžeme vidiet', že medzi matematicky nadanými adolescentmi a bežnými adolescentmi existuje rozdiel v škále neurotizmu. Matematicky nadaní žiaci sú signifikatné $U=458,00 ; p<0,05$ $(\mathrm{p}=0,001)$ menej neurotickí ako bežní žiaci. V ostatných škálach sa štatisticky významné rozdiely nepreukázali.

Neurotizmus (alebo emočná labilita) sa v kontexte tohto dotazníka poníma ako intenzívne a časté prežívanie negatívnych emócií. Neurotickí l'udia sú impulzívni a majú slabú odolnost' voči stresu. Pri vysvetlení prečo matematicky nadaní žiaci vykazujú nižšiu mieru neurotizmu môžeme vychádzat' zo špecifických charakteristík matematicky nadaného jedinca uvedených v teoretických východiskách. Nadaní žiaci majú lepšiu výdrž v t’ažkých situáciách a samostatné myslenie s tendenciou k vysokému výkonu (Hribkova, 2009; Laznibatova, 2012). K tomu sa pridávajú kognitívne charakteristiky ako logickost' a racionálnost' v myslení (Hribkova, Laznibatova, Juraskova; in Kovarova - Klugova, 2010), z čoho sa dá dedukovat' silný príklon $\mathrm{k}$ racionálnemu uvažovaniu na úkor emočného prežívania. Nie je preto prekvapením, že títo adolescenti majú schopnost' lepšie zvládat' negatívne a stresujúce situácie, čo sa $\mathrm{v}$ našom výskume preukázalo ako nižšia miera neurotizmu.

$\mathrm{Na}$ základe uvedených výsledkov môžeme konštatovat', že matematicky nadaní žiaci sú skutočne jedinci so svojskou osobnostnou štruktúrou. Nielenže sa výrazne líšia od bežných žiakov, ale je pravdepodobné, že svojimi charakteristikami sa výrazne odlišujú aj od nadaných žiakov bez špecifického matematického nadania. Viacerí autori (napr. Sword, 2012) totiž uvádzajú u bežných nadaných žiakov intenzívne emočné prežívanie, kvôli ktorému sa nadaní cítia odlišne, majú viac skúseností s vnútornými konfliktami, sú úzkostnejší a depresívnejší. Náš výskum preukázal, že matematicky nadaní žiaci sú naopak menej neurotickí, čo naznačuje ich vel'ký pracovný potenciál. Uvedené úvahy je však nutné dôsledne preskúmat'.

\section{Záver}

Výskum nám preukázal špecifickú osobnostnú štruktúru matematicky nadaných adolescentov a jej odlišnost' od bežnej populácie. Vzhl'adom na vynikajúce kognitívne a osobnostné charakteristiky matematicky nadaných študentov považujeme za dôležité venovat' im plnú pozornost', pretože sú to práve oni, ktorí môžu významne prispievat' k rozvoju spoločnosti. Tento fakt si mnohé krajiny uvedomili už dávnejšie, čoho dôkazom je výrok: 
"vynikajúce matematické schopnosti sú vzácnym zdrojom pre spoločnost', zúfalo potrebným na udržanie prvenstva v technologickom svete" (National Council of Teachers of Mathematics; in Johnson, 2000).

\section{Bibliography}

AMTHAUER, R. 1993. Test struktury inteligencie I-S-T 70. Prirucka na administraciu a vyhodnocovanie. Uprava J. Vonkomer. Bratislava: Psychodiagnostika.

BURJAN, V. 2005. Zamyslenie nad niektorymi didaktickymi a psychologickymi aspektmi prace s matematickymi talentami. In: Ani jeden matematický talent nazmar. Sbornik prispevku 2. rocniku konference ucitelu matematiky a prirodnich oboru na zakladnich, strednich a vysokych skolach. Prague: UK PF. ISBN 8072902245.

CLARK, B. 2012. Growing up Gifted. Developing the Potential of Children at Home and at School, 8th edition, Los Angeles: Pearson. ISBN 9780132620666.

COLANGELO, N. - DAVIS, G. A. E. 2003. Handbook of Gifted Education. 3rd edition. Boston: Pearson Education, Inc. ISBN 0-20534063-6.

DAVIS, A. G. - RIMM, B. S. - SIEGLE, D. 2010. Education of the Gifted and Talented. 6th edition. New York: Pearson. ISBN 0135056071.

DIEZMAN, C. M. - WATTERS, J. J. 2001. The collaboration of mathematically gifted students on challenging tasks. Journal for the Education of the Gifted., vol. 25, n. 1, pp. 7-31. ISSN 01623532.

DIEZMAN, C. - WATTERS, J. 2002. Summing up the education of mathematically gifted students. Proceedings 25th Annual Conference of the Mathematics Education Research Group of Australasia. pp. 219-226.

DOCKAL, V. - MUSIL, M. - PALKOVIC, V. - MIKLOVA, J. 1987. Psychologia nadania. Bratislava: SPN.

HRIBKOVA, L. 2009. Nadani a nadani. Pedagogicko-psychologicke pristupy, modely, vyzkumy a jejich vztah ke skolské praxi. Praha: Grada Publishing. ISBN 978-80-247-1998-6.

JOHNSON, D. 2000. Teaching Mathematics to Gifted Students in a MixedAbility Classroom. In The Council for Exceptional Children. [cit. 2015-0528]. Available online: http://www.gifted.uconn.edu/siegle/tag/ Digests/e594.html

JOHNSEN, S. - KENDRICK, J. 2005. Math Education for Gifted Students. Waco: Prufrock Press. ISBN 978-1593631666.

KOMPANOVA, V. 2013. Praca s matematicky nadanymi ziakmi. Osvedcena pedagogicka skusenost edukacnej praxe. Banska Bystrica.

KOVAROVA, R. - KLUGOVA, I. 2010. Edukace nadanych deti a zaku. 1. vyd. Ostava: Ostravska univerzita v Ostrave. ISBN 978-80-7368-430-3. LAZNIBATOVA, J. 2012. Nadany ziak na zakladnej, strednej a vysokej skole. Bratislava: IRIS. ISBN 978-80-89256-87-7.

LAZNIBATOVA, J. 2007. Nadane dieta. Jeho vyvin, vzdelavanie a podporovanie. 3. vyd. Bratislava: IRIS. ISBN 80-89018-53-X. 
LAZNIBATOVA, J. - VRANKOVA, L. 2005. Vlastnosti a prejavy osobnosti nadaných deti. Ostatnikova, L. (Ed.), Specifika vyvinu a realizacia potencialu nadanych deti: Zbornik prac zo 4. medzinarodnej konferencie. Bratislava: Asklepios. ISBN 80-7167-087-1.

MANN, E. L. 2006. Creativity: The Essence of Mathematics. In: Journal for the Education of the Gifted, vol. 30, n. 2, pp. 236-260. ISSN 0162-3532 MALINOVA, D. 2013. Matematicke nadani. Svet nadani. Casopis o nadani a nadanych, Vol. 2, Issue. 1, pp. 14-21. ISSN 1805-7217.

METODICKE pokyny na zaradovanie deti do specialnych vychovnovzdelavacich programov pre intelektovo nadanych ziakov. 2008. [cit. 201506-01]. Available online: www2.statpedu.sk/buxus/docs/integracia/ integrnadan2.pdf.

MONKS, F. J. - YPENBURG, I. 2002. Nase dite je velmi nadane. 1. vyd. Praha: Grada Publishing. ISBN 80-247-0445-5.

MONTGOMERY County Public Schools. 2015. Characteristics of Highly Able Math Students. [cit. 201-08-10]. Available online: www.montgomeryschoolsmd.org/

curriculum/enriched/parents/characteristics-math.aspx

PLETAN, M. D. - ROBINSON, N. M. - BERNINGER, V. W. - ABBOTT, R. D. 1995. Parents' observations of kindergarteners who are advanced in mathematical reasoning. Journal for the Education of the Gifted, vol. 19, pp. 30-44. ISSN 01623532.

ROTIGEL, J. - FELLO. 2004. Mathematically Gifted Students: How Can We Meet Their Needs. In Gifted Child Today. ISSN 1076-2175, 2004, vol. 27, no. 4, pp. 46-51

RUISEL, I. - HALAMA, P. 2001. NEO pat faktorovy osobnostny inventar. Prague: Testcentrum-Hogrefe.

SRIRAMAN, B. 2009. Mathematical Intelligence. In B. Kerr (Ed.), Encyklopedia of giftedness, creativity, and talent I., II. Washington DC: SAGE Publications. ISBN 9781412949712.

SWORD, L K. 2012. Emotional Intensity in Gifted Children. [cit. 2015-0702]. Available online: www.sengifted.org/archives/articles/

emotional-intensity-in-gifted-children

VASUTOVA, A. 2012. Vplyv skolskej edukacie na rozvijanie matematickeho nadania ziaka 1. rocnika primarnej skoly. Presov: Presovska univerzita. ISBN 9788055506548.

WECHSLER, D. 2006. Wechslerova inteligencna skala pre deti. 1. slovenske vydanie. Prague: Testcentrum - Hogrefe.

PaedDr. Dušan Fábik

Comenius University

Faculty of Pedagogy, Department of Psychology

Moskovská 3, 81108 Bratislava

Slovakia

fabik7@uniba.sk 